\title{
Short Communication: Ant (Hymenoptera: Formicidae) diversity as bioindicator of agroecosystem health in northern slope of Mount Slamet, Central Java, Indonesia
}

\author{
IMAM WIDHIONO״, RIZKITA DINDA PANDHANI, DARSONO, EDI RIWIDIHARSO, SLAMET SANTOSO, \\ LUCKY PRAYOGA
}

Faculty of Biology, Universitas Jenderal Soedirman. Jl. Dr. Soeparno 63, Purwokerto, Banyumas 53122, Central Java, Indonesia. Tel. +62-281638794, Fax.: +62-281-631700, `email: imamwidhiono@yahoo.com

Manuscript received: 21 May 2017. Revision accepted: 26 September 2017.

\begin{abstract}
Widhiono I, Pandhani RD, Darsono, Riwidiharso E, Santoso S, Prayoga L. 2017. Short Communication: Ant (Hymenoptera: Formicidae) diversity as bioindicator of agroecosystem health in northern slope of Mount Slamet, Central Java, Indonesia. Biodiversitas 18: 1475-1480. This study examined the diversity of ant assemblages in two different agroecosystems (organic and intensive farming) with maize as main crops on the northern slope of Mount Slamet, Indonesia from April to August 2015. The response of ant diversity to the different farming systems was evaluated. In total, 359 ants from 17 species in five subfamilies were collected: 13 species from the organic farm and 10 species from the conventional farm. Seven (41\%) species were found only on the organic farm, four $(23 \%)$ species were found only on the conventional farm, and six $(35 \%)$ species were found on both. The Morisita-Horn similarity index $(33 \%)$ showed that the similarity of the species composition in the two habitats was low. More individual ants were found on the organic farm than the intensive farm [287 (79.94\%) vs. $72(20.05 \%)$ individuals]. The diversity of the ants was affected by the density of weeds with organic farming. Hypoponera sp. had the highest Indicator Value (50.7), followed by Aphaenogaster sp. (28.9), Diacamma sp. (28.2), and Odontoponera sp. (27.6), however only Odontoponera sp can be used as bioindicator. Although the ant diversity was higher with organic farming than with intensive farming, there was no correlation with soil conditions. As a bioindicator, the Indicator Value reflects agroecosystem health better than does ant diversity.
\end{abstract}

Keywords: bioindicators, indicator value, intensive farming, organic farming

\section{INTRODUCTION}

Recent agricultural intensification and structural changes in the agricultural landscape have led to the overuse of agrochemicals, which in turn has caused a decline in farmland biodiversity. Intensive agricultural practices drive biodiversity loss with potentially drastic consequences for ecosystem services. Increased awareness of the high environmental costs of agricultural intensification has prompted a search for solutions that promote the preservation and restoration of natural resources (Mone et al. 2014). To advance conservation and production goals, agricultural practices should be compatible with biodiversity. In organic farming, crops are grown using organic waste and other biological materials along with beneficial microbes (biofertilizers) for increased sustainable production without spoiling soil health. Organic agriculture is a unique production management system that promotes and enhances agroecosystem health, including biodiversity, biological cycles, and soil biological activity, and this is accomplished using on-farm agronomic, biological, and mechanical methods that exclude all synthetic off-farm inputs (Jahanban and Davari 2012). Organic farming contributes to the preservation and enhancement of biodiversity, but it is unable to ensure sufficiently high production levels (Hole et al. 2005; Rundlöf et al. 2010).
Ants are important components of ecosystems, not only because they constitute a significant portion of the animal biomass but also because they act as ecosystem engineers. Ant biodiversity is incredibly high, and these organisms are very responsive to human impacts, which obviously reduce their richness. However, it is not clear how such disturbances damage the maintenance of ant services to the ecosystem. Ants are important in below-ground processes by altering the physical and chemical environments and affecting plants, microorganisms, and other soil organisms. Kinasih et al. (2016) found that the family Formicidae (ants) is dominant in coffee-pine agroforests compared with pine forests and is an important part of the litter decomposition process (Musyafa 2005). The diversity of ants is correlated with the above-ground vegetation as food resources and protects against environmental disruption (Rubiana et al. 2015). Organic farming results in higher weed diversity than does intensive farming (Mone et al. 2014). Widhiono et al. (2017) found that vegetation cover affected the diversity of endemic dung beetles. The diversity and abundance of ants differed significantly according to habitat type in Jambi (Yuniar and Haneda 2015), and ant diversity shows strong negative responses to agricultural practices such as fertilization, pesticide spraying, and burning (Uno et al. 2010)

Many ant species are very sensitive to microclimate fluctuations and habitat structure and respond strongly to 
environmental changes (Paknia and Pfeiffer 2011). Rizali et al, (2013) found precipitation as the main environmental factors that affected ant communities. Increasing agricultural practices in intensive farming systems will decrease ant diversity, which alters the affected area (Andersen and Majer 2004). Ants are sensitive to disturbances and rehabilitation (Andersen et al. 2002), and diversity shows strong negative responses to agriculture intensification (Philpott 2010). Ants are considered suitable bioindicator species of ecosystem health because of their ecological significance in agroecosystems (Alonso 2000). Most habitats are likely to have specialized species, which occur when species diversity and abundance are sufficient, and these species serve as suitable terrestrial indicator species of habitat quality and changes. However research on ant diversity for agroecosystem health is very rare in Java and therefore this study was carried out to compare the diversity of ants between intensive and organic farming systems and analyze the potential of ants as bioindicators of agroecosystem health in each system.

\section{MATERIALS AND METHODS}

\section{Study area}

The study was conducted in Nyalembeng Village $\left(7^{\circ} 10^{\prime}, 01.76^{\prime \prime} \mathrm{S}\right.$ and $\left.109^{\circ} 14^{\prime}, 46.60^{\prime \prime} \mathrm{E}\right)$ in the highland district on the northern slope of Mount Slamet, in Sub-district of Pulosari, District of Pemalang, Central Java Province, Indonesia. On the organic farm, the farmer applies only organic fertilizers such as farmyard manure, vermicompost, and biofertilizers. The farmer followed organic farming practices for the previous 3 years in the same field. The conventional farm, on which chemical fertilizers and chemical pesticides (herbicide atrazine $600 \mathrm{~g} / \mathrm{L}$ with doses $1.5 \mathrm{~L} / \mathrm{ha}$ ) were applied, was located in the same village. This farmer used chemical pest control and crop management and applied synthetic fertilizers such as urea and phosphate. A 1-acre maize field area was selected for insect sampling on both the organic and chemical farms. Both fields were surrounded by maize cultivation (Figure 1)
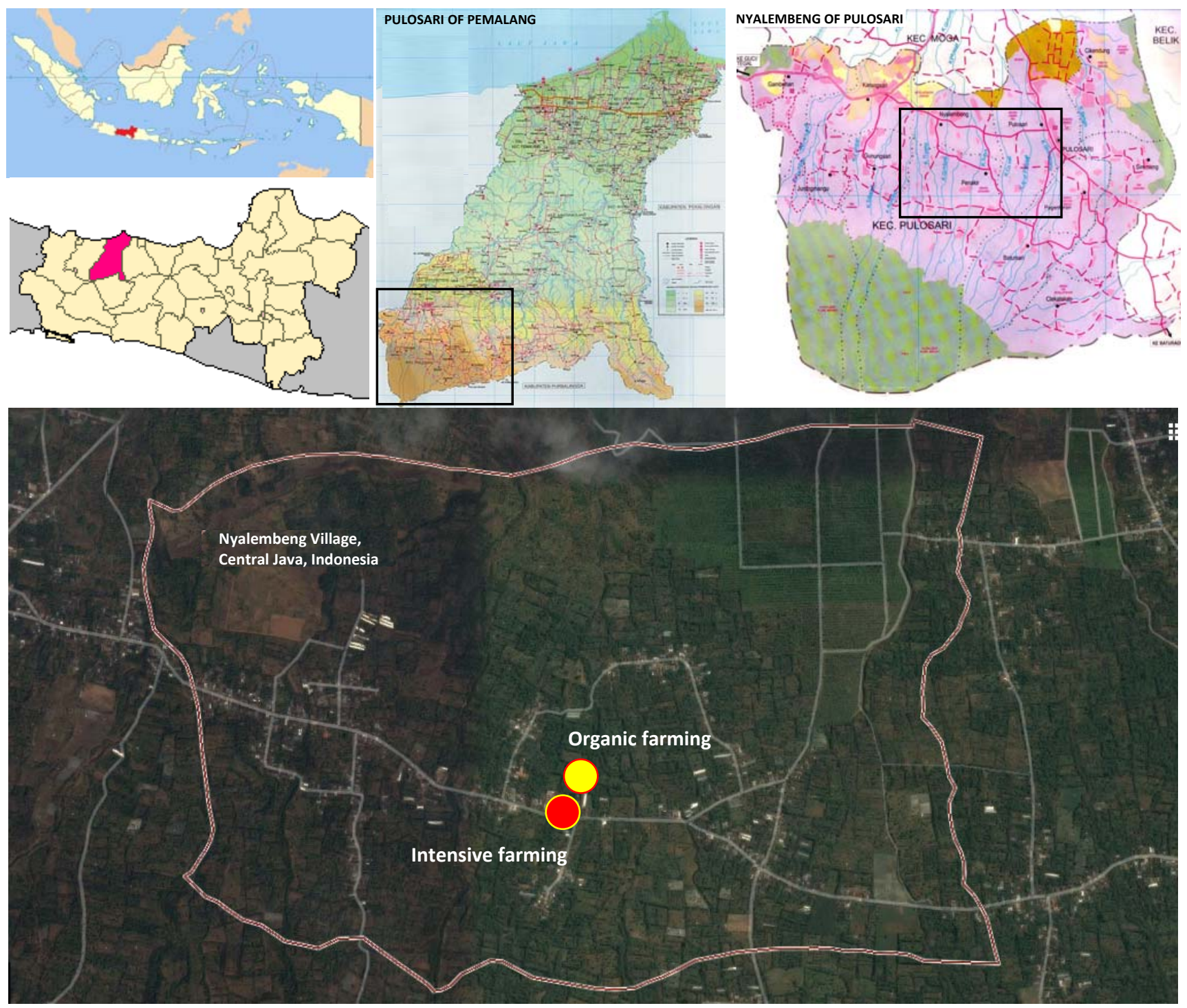

Figure 1. Sampling location in Nyalembeng Village, Sub-district of Pulosari, District of Pemalang, Central Java Province, Indonesia 


\section{Ant collection}

Ants were collected from 10 random $1 \mathrm{~m} \times 1 \mathrm{~m}$ quadrates in each farm using pitfall traps. Sampling was conducted five times from April to August 2015. Ants were identified using Fayle (2010).

\section{Ant functional groups}

Ant functional groups were classified according to Andersen et al. (2004), and Brown (2000) as follows: (i) Dominant Dolichoderinae (DD): genera Iridomyrmex, (ii) Subordinate Camponotini (SC): genera Camponotus, Echinopla, Polyrhachis, (iii) Tropical-climate Specialists (TCS): genera Cladomyrma, Tetraponera, Myrmecina, Solenopsis, Dolichoderus, Myrmicaria, Vollenhovia, Epelysidris, Acanthomyrmex, Pristomyrmex, Anoplolepis, Acropyga, (iv) Opportunists (O): genera Tetramorium, Paratrechina, Paraparatrechina, Nylanderia, Cardiocondyla, Technomyrmex, Tapinoma, Aphaenogaster, Ochetellus, (v) Generalized Myrmicinae (GM): genera Pheidole, Crematogaster, Monomorium, (vi) Specialist Predators (SP): genera Pachycondyla, Odontoponera, Anochetus, Leptogenys, Platythyrea, (vii) Cryptic species (C): genera Mayriella, Ponera, Carebara, Hypoponera, Pheidologeton, Plagiolepis, Mystrium, Dacetinops, Calyptomyrmex, Amblyopone, Strumigenys, Procertium, Probolomyrmex, Eurhopalothrix, Centromyrmex, Cryptopone, Discothyrea, Protanilla, Cerapachys

\section{Measurement of environmental factors}

For each farming system, five soil samples were collected, and two soil physical characteristics (soil humidity and soil temperature) and one chemical characteristic (soil pH) were measured. Vegetation in each plot was quantified as the measured weed density per square meter.

\section{Data analysis}

The total number of individuals of each ant species collected was recorded. Shannon's index $\left(\mathrm{H}^{\prime}\right)$, Fisher's alpha $(\alpha)$, and the Simpson (D) and Evenness (E) indices were derived from data collected from both organic and conventional farming. PAST software was used to calculate the diversity indices.

The Indicator Value (IV) for each ant species was calculated using Dufrêne and Legendre's (1997) IV method (Dai et al. 2006) with the formula: IV $=\mathrm{RA} \times \mathrm{RF} \times 10$; where, RA is the relative abundance determined by the formula $\mathrm{RA}=n / N \times 100 \%$, where $n$ is the number of individuals of a specific species recorded, and $N$ is the total number of individuals recorded. Similarly, the relative frequency of occurrence (RF) was calculated as $R F=f / F \times$ $100 \%$, where $f$ is the frequency of detecting a particular species, and $F$ is the total number of species recorded. The IV ranges from 0 (no indication) to 100 (perfect indication).

Simple correlation analysis was used to evaluate the impacts of environmental factors and vegetation complexity and density on ant diversity.

\section{RESULTS AND DISCUSSION}

Ant diversity and abundance were compared between organic and intensive farming. During the study, 17 ant species belonging to 16 genera and five subfamilies were identified from a sample of 321 workers. Of the subfamilies, Ponerinae was dominant in terms of species richness (5 species) and abundance, followed by Myrmicinae and Dolichoderinae (4 species each), Formicinae (3 species each), and Pseudomyrmecinae (1 species). Comparing the ant communities, more ant species were detected in organic farming (13 species) than conventional farming (10 species): seven species (Odontoponera sp., Acanthomyrmex sp., Pristomyrmex sp., Tetramorium sp., Prenolepis sp., Cladomyrma sp., and Iridomyrmex sp. (41\%) were found only on the organic farm, comparing only four species (Hypoponera sp. 2, Emeryopone sp., Technomyrmex sp., and Tapinoma sp.) $(23 \%)$ were on the conventional farm, and six species (Diacamma sp., Hypoponera sp. 1, Aphaenogaster sp., Lepisiota sp., Dolichoderus sp., and Tetraponera sp.) $(35 \%)$ were found on both farms (Table 1, Figure 2).

This result showed that more ant species and greater ant abundance were recorded on organic farms. This is in line with the result of Bharti et al. (2016) who has done the research of ants as bioindicators of ecosystem health in Shivalik Mountains of Himalayas. This finding could be explained by the intrinsic need for resources and biotope condition patterns required by each ant species, and because a more structured and complex habitat provides the best environmental conditions for all ants and relative habitat structure can induce major variability in ant diversity. In Jammikunta, India, ant diversity was affected by vegetation structure (Ravi et al. 2015), but Rizali et al. (2013) found that the main factor of dissimilarity of ants communities was precipitation rate. Vegetation structure may improve soil invertebrate abundance and the diversity, Kinasih et al. (2016) found that the diversity of soil macroinvertebrates was highest on a coffee plantation and lowest on a pine plantation. Agroforestry may improve soil invertebrate abundance and the diversity of monoculture pine forests through the creation of additional and alternative nutrition and microhabitats. However, Yudiyanto et al. (2014) obtained different results and found that the farming system on pepper plantations had no significant effect on ant diversity, while habitat conditions and the surrounding habitats had greater effects on ant diversity. In general, agricultural practices such as heavy grazing, irrigation, drainage, fertilization, mowing, conventional tillage, plowing, and reseeding reduce ant biodiversity and colony densities (Rubiana et al. 2015). Despite this reduction in biodiversity, ants seem to tolerate, recover, or re-invade the same areas after disturbance (Folgarait 1998). 
Table 1. Species richness, relative abundance (RA\%), relative frequency (RF\%), indicator value (IV) and functional groups (FG) of ants in organic farming (OF) and intensive farming (IF)

\begin{tabular}{|c|c|c|c|c|c|c|c|c|c|c|}
\hline \multirow[t]{2}{*}{ Family } & \multirow[t]{2}{*}{ Species } & \multicolumn{5}{|c|}{ OF } & \multicolumn{3}{|c|}{ IF } & \multirow[t]{2}{*}{ FG } \\
\hline & & & RA (\%) & RF (\%) & IV & & RA (\%) & RF \% & IV & \\
\hline \multirow{5}{*}{ Ponerinae } & Odontoponera sp. & 86 & 17.2 & 60 & 27.6 & 0 & & & & $\mathrm{P}$ \\
\hline & Diacamma sp. & 77 & 15.4 & 26.36 & 26.82 & 2 & 2.8 & 40 & 28.2 & $\mathrm{O}$ \\
\hline & Hypoponera sp.1 & 23 & 4.6 & 100 & 46.2 & 35 & 50.7 & 100 & 50.7 & $\mathrm{C}$ \\
\hline & Hypoponera sp.2 & 0 & & & & 3 & & & & $\mathrm{C}$ \\
\hline & Emeryopone sp. & 0 & & & & 1 & & & & $\mathrm{C}$ \\
\hline \multirow[t]{4}{*}{ Myrmicinae } & Aphaenogaster sp. & 50 & 10 & 100 & 17.1 & 20 & 28.98 & 100 & 28.9 & $\mathrm{O}$ \\
\hline & Acanthomyrmex sp. & 2 & 0.4 & 0.6 & & 0 & & & & TCS \\
\hline & Pristomyrmex sp. & 2 & 0.4 & 0.6 & & 0 & & & & TCS \\
\hline & Tetramorium sp. & 2 & 0.4 & 0.6 & & 0 & & & & TCS \\
\hline \multirow[t]{3}{*}{ Formicinae } & Prenolepis sp. & 3 & 0.6 & 1 & & 0 & & & & TCS \\
\hline & Cladomyrma sp. & 5 & 1 & 1.7 & & 0 & & & & TCS \\
\hline & Lepisiota sp. & 14 & 1.8 & 4.7 & & 1 & & & & $\mathrm{C}$ \\
\hline \multirow[t]{4}{*}{ Dolichoderinae } & Dolichoderus sp. & 10 & 2 & 3.42 & & 1 & & & & DD \\
\hline & Iridomyrmex sp. & 14 & 2.8 & 4.7 & & 0 & & & & DD \\
\hline & Technomyrmex sp. & 0 & & & & 2 & & & & DD \\
\hline & Tapinoma sp. & 0 & & & & 1 & & & & DD \\
\hline Pseudomyrmecinae & Tetraponera sp. & 4 & 0.8 & 1.3 & & 3 & & & & TCS \\
\hline
\end{tabular}

The density and complexity of weeds were greater in organic farming than in intensive farming. We found 28.2 individuals $/ \mathrm{m}^{2}$ and eight species on the organic farm and 8.6 individuals $/ \mathrm{m}^{2}$ and six species on the conventional farm (Table 2). This difference might result from the weeding method: hand mowing was used with organic farming, while herbicides were used with intensive farming. According to El Sebai and El Tawil (2012), most foliar pesticides are toxic to many non-target organisms, such as beneficial arthropods, including predators and parasitoids. The correlation analysis showed a strong relationship between ant diversity and weed density $(r=0.76)$ and a weaker relationship between ant diversity and weed complexity $(\mathrm{r}=0.36)$. We hypothesized that organic farming, which involves relatively high weed density and complexity, creates a wider potential diversity of available ecological niches. Our findings were consistent with this hypothesis, since the ant species richness and diversity differed significantly with vegetation structure.
Vasconcelos et al. (2008) found that vegetation structure and vegetation cover affected ant diversity in Amazonian savannah. Ant community structure also differed among the vegetation domains evaluated in Brazilian tropical dry forest (Silva et al. 2017).

The Species Richness (S), Shannon-Wieners Diversity Index $\left(\mathrm{H}^{\prime}\right)$, and Evenness $(\mathrm{J})$ differed between the two habitats. There was less variation in the ant $\mathrm{H}^{\prime}$ in the organic field $\left(\mathrm{H}^{\prime}=1.006-1.791\right)$ than in the intensive field $\left(\mathrm{H}^{\prime}=0.8532-1.494\right)$. Values greater than 1.00 indicate that the habitat supports the survival of ant species. J ranged from 0.4382 to 0.7496 in the organic field and from 0.5241 to 0.8911 in the intensive field. Examining the correlations between diversity and environmental parameters, there were weak correlations of diversity with soil $\mathrm{pH}(\mathrm{r}=0.23)$ and soil humidity $(\mathrm{r}=0.37)$. This result was in accordance with Jacquemin et al. (2012), who found that soil properties weakly affected the subterranean ant distribution at small spatial scales.

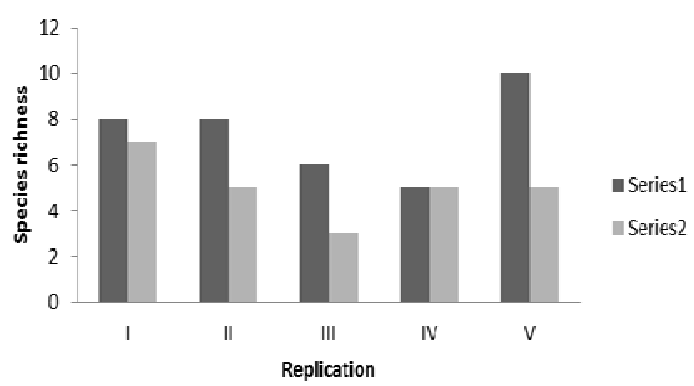

$\mathbf{A}$

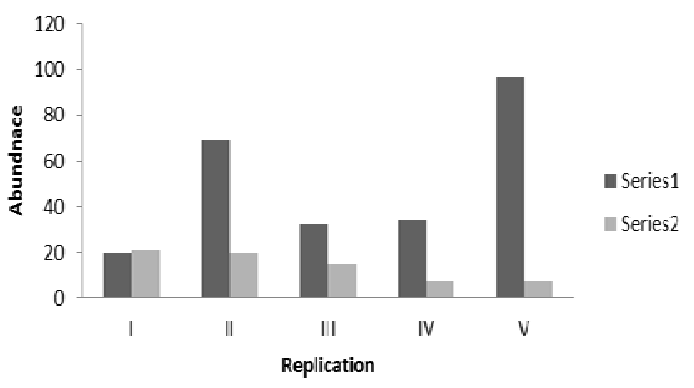

B

Figure 2. A. Species richness, B. Abundance of ants in organic farming and intensive farming 
Table 2. Species richness and density of weeds in organic farming (OF) and intensive farming (IF)

\begin{tabular}{|c|c|c|c|c|c|c|c|c|c|c|}
\hline \multirow{2}{*}{ Species } & \multicolumn{5}{|c|}{$\mathbf{O F}$} & \multicolumn{5}{|c|}{ IF } \\
\hline & 1 & 2 & 3 & 4 & 5 & 1 & 2 & 3 & 4 & 5 \\
\hline Amaranthus spinosus & 5 & 3 & 0 & 2 & 5 & 0 & 0 & 0 & 2 & 0 \\
\hline Ageratum conyzoides & 0 & 1 & 4 & 4 & 1 & 0 & 1 & 0 & 4 & 1 \\
\hline Ipomoea sp. & 2 & 5 & 5 & 3 & 4 & 2 & 0 & 5 & 3 & 0 \\
\hline Alternanthera philoxeroides & 9 & 5 & 0 & 3 & 5 & 0 & 5 & 0 & 3 & 0 \\
\hline Synedrella nodiflora & 2 & 3 & 6 & 2 & 6 & 2 & 3 & 0 & 2 & 0 \\
\hline Portulaca oleracea & 5 & 3 & 5 & 5 & 5 & 5 & 3 & 2 & 0 & 0 \\
\hline Physalis longifolia & 7 & 4 & 0 & 7 & 0 & 0 & 0 & 0 & 0 & 0 \\
\hline Galinsoga ciliata & 4 & 5 & 2 & 0 & 4 & 0 & 0 & 0 & 0 & 0 \\
\hline Total & 34 & 29 & 22 & 26 & 30 & 9 & 12 & 7 & 14 & 1 \\
\hline Means & 4.25 & 3.62 & 2.75 & 3.25 & 3.75 & 1.12 & 1.5 & 0.875 & 1.75 & 0.25 \\
\hline
\end{tabular}

Table 3. Diversity parameters of ants and the environmental factors in organic and intensive farming

\begin{tabular}{|c|c|c|c|c|c|c|c|c|c|c|}
\hline \multirow{2}{*}{ Parameter } & \multicolumn{5}{|c|}{ Organic farming } & \multicolumn{5}{|c|}{ Intensive farming } \\
\hline & I & II & III & IV & $\mathbf{V}$ & I & II & III & IV & $\mathbf{V}$ \\
\hline Taxa $S$ & 8 & 8 & 6 & 5 & 10 & 7 & 5 & 3 & 5 & 5 \\
\hline Individuals & 20 & 69 & 32 & 34 & 97 & 21 & 20 & 15 & 8 & 8 \\
\hline Dominance_D & 0.22 & 0.4068 & 0.2715 & 0.4948 & 0.2282 & 0.415 & 0.34 & 0.4756 & 0.25 & 0.25 \\
\hline Shannon_H & 1.791 & 1.254 & 1.476 & 1.006 & 1.789 & 1.3 & 1.257 & 0.8532 & 1.494 & 1.494 \\
\hline Simpson_-1-D & 0.78 & 0.5932 & 0.7285 & 0.5052 & 0.7718 & 0.585 & 0.66 & 0.5244 & 0.75 & 0.75 \\
\hline Evenness_- $\mathrm{e}^{\wedge} \mathrm{H} / \mathrm{S}$ & 0.7496 & 0.4382 & 0.7294 & 0.5467 & 0.5981 & 0.5241 & 0.7027 & 0.7824 & 0.8911 & 0.8911 \\
\hline Soil PH & 6.4 & 7 & 7 & 6.8 & 6.8 & 7 & 6.8 & 6.8 & 7 & 6.8 \\
\hline Soil humidity (\%) & 70 & 80 & 50 & 40 & 60 & 50 & 50 & 55 & 40 & 50 \\
\hline Weed complexity & 5 & 5 & 4 & 4 & 6 & 3 & 3 & 2 & 3 & 3 \\
\hline Weed density & 41 & 47 & 35 & 35 & 56 & 13 & 24 & 3 & 6 & 6 \\
\hline
\end{tabular}

Of the 17 species detected in this study, only 4 were sufficiently abundant to calculate the IV, which was highest for Hypoponera sp. 1. (50.7), followed by Aphaenogaster sp. (28.9), Diacamma sp. (28.2), and Odontoponera sp. (27.6). However, according to Sitthicharoenchai and Chantarasawat (2006), only Odontoponera sp. can be used as a bioindicator species, because as a predator, it is very sensitive to habitat disturbances. The three other species (Hypoponera sp., Aphaenogaster sp. and Diacamma sp.) are generalist species and are usually abundant in all habitat conditions. Suputa et al. (2007) found Odontoponera sp. dominated in home yard and was an important predator of aphids and fruit flies in Yogyakarta. According to Read and Anderson (2000), one approach to analyzing changes in ant community composition is to focus on functional groups whose abundances vary with environmental stress and disturbance. In this study site (Nyalembeng), the result showed that both agricultural systems were dominated by generalists, this condition may because of the history of this field which has been construct to organic farming during recent three years (this sentence is not clear). A fairly large number of generalist ant species in both fields may exist because of the tendency of ant species to inhabit man-made habitats. This result was in accordance with Rubiana et al. (2015) who carried out research in four different habitats in Jambi. The use of such functional groups allows prediction of the community response to disturbances in the absence of species-level information and provides an ecological context for interpretations of compositional changes. Functional groups have been used successfully to monitor land-uses inducing marked ecological changes (Read and Andersen 2000).

In conclusion, the relative contributions of organic and intensive farming to ant diversity differed and were higher for organic farming. However, there were no correlations with soil conditions. In term of bioindicator attributes, ant functional groups are more sensitive in reflecting agroecosystem health than is ant diversity. However, in this study, we found that ant diversity was higher in organic farming than in intensive farming and conclude that organic farming leads to a healthier ecosystem than does intensive farming.

\section{ACKNOWLEDGEMENTS}

We thank the farmers in Pulosari, Pemalang, Indonesia for supporting this research and all of the students who assisted in collecting the field data. 


\section{REFERENCES}

Alonso LA. 2000. Ants an indicator of diversity, In: Agosti D. (ed.) Ants Standard Methods for Measuring and Monitoring Biodiversity. Smithsonian Institution Press, Washington, DC.

Andersen AN, Hoffmann BD, Muller WJ, Griffiths AD. 2002. Using ants as bioindicators in land management: simplifying assessment of ant community responses. J App Ecol 39: 8-17.

Andersen AN, Majer JD. 2004. Ants show the way Down Under: invertebrates as bioindicator in land management. Front Ecol Environ 2: 291-298.

Bharti H, Bharti M, Pfeiffer M. 2016. Ants as bioindicators of ecosystem health in Shivalik Mountains of Himalayas: assessment of species diversity and invasive species. Asian Myrmecol 8: 1-15.

Brown WL. 2000. Diversity of ants. In: Agosti D, Majer JD, Alonso LE, Schultz TR (eds.). Ants: Standard Methods for Measuring and Monitoring Biodiversity; Smithsonian Institution Press: Washington, DC, USA.

Dai X, Page B, Duffy KJ. 2006. Indicator value analysis as a group prediction technique in community classification. S A J Bot 72: 589596.

Dufrêne M, Legendre P. 1997. Species assemblages and indicator species: the need for a flexible asymmetrical approach. Ecol Monogr 67: 345 366.

El Sebai OA, El-Tawil MF. 2012. Side-effect of certain herbicides on egg parasitoid Trichogramma evanescens (West.) (Hymenoptera: Trichogrammatidae). Acad J Entomol 5 (1): 1-10.

Fayle T. 2010. Key to the Workers of 100 Ant Genera and 12 Ant Subfamilies

Borneo. www.tomfayle.com/Key\%20to\%20the $\% 20$ ant $\% 20$ genera $\% 2$

Folgarait PJ. 1998. Ant biodiversity and its relationship to ecosystem functioning: a review. Biodiv Conserv 7: 1221-1244.

García-Martínez MA, Martínez-Tlapa DL, Toledo GRP, Quiroz-Robledo LN, Castaño-Meneses G, Laborde J, Valenzuela-González JE. 2015. Taxonomic, species and functional group diversity of ants in a tropical anthropogenic landscape. Trop Conserv Sci 8 (4): 1017-1032.

Hole DG, Perkins AJ, Wilson JD, Alexander IH, Grice PV, Evans AD 2005. Does organic farming benefit biodiversity? Biol Conserv 122 (1):113-130.

Jacquemin J, Drouet T, T Delsinne T, Roisin Y, Leponce M. 2012. Soil properties only weakly affect subterranean ant distribution at small spatial scales. Appl Soil Ecol 62: 163-169.

Jahanban, L, Davari, M. 2012. Standards and certification procedures in organic agriculture: An overview focusing on organic crop production. Int Res J Appl Basic Sci 3 (9): 1825-1836.

Kinasih I, Cahyanto T, Widiana A, Nurbah D, Kurnia I, Julita U, Putra RE. 2016. Soil invertebrate diversity in coffee-pine agroforestry system at Sumedang, West Java. Biodiversitas 17 (2): 473-478.
Mone K, Kusha KM, Jathanna D, Ali M, Goel A, 2014. Comparison of insect biodiversity between organic and conventional plantations in Kodagu, Karnataka, India. J Threaten Taxa 6 (9): 6186-6194.

Musyafa. 2005. The roles of soil macrofauna on litter decomposition of Acacia mangium Willd. Biodiversitas 6 (1): 63-65.

Paknia O, Pfeiffer M. 2011. Steppe versus desert: multi-scale spatial patterns in diversity of ant communities in Iran. Insect Conserv Divers 4: 297-306.

Philpott S, Perfecto I, Armbrecht I, Parr CL. 2010. Ant diversity and function in disturbed and changing habitats. In: Lach L, Parr CL, Abbott KL (eds.). Ant Ecology. 1st edn. Oxford University Press, Oxford.

Ravi N, Sravanthy CH, Sammaiah CH, Thirupathaiah M. 2015. Biodiversity of ants (Insecta-Hymenoptera) in agro-ecosystem and grassland in Jammikunta, Karimnagar District, Telangana, India. J Environ 4 (1): 11-16.

Read JL, Andersen AN. 2000. The value of ant's as early warning bioindicators: responses to pulsed cattle grazing at an Australian arid zone locality, J Arid Environ 45: 231-251.

Rizali A, CloughY, Buchori D, Transchtke T, 2013. Dissimilarity of ant communities increase with precipation, but not reduced land-use intensity, in Indonesia cacao agroforestry. Diversity 5: 26-38.

Rubiana R, Rizali A, Denmead LH, Alamsari W, Hidayat P, Pudjianto, Hindayana Y, Clough Y, Tscharntke T, Buchori D. 2015. Agricultural landuse alters composition but not species richness of ant communities. Asian Myrmecol 72: 73-85.

Rundlöf M, Edlund M, Smith H G. 2010. Organic farming at local and landscape scales benefits plant diversity. Ecography 33: 514-522.

Silva LF, Souza RM, Solar RC, Neves FS. 2017. Ant diversity in Brazilian tropical dry forests across multiple vegetation domains. Environ Res Lett 12 035002. DOI: 10.1088/1748-9326/aa5f2a

Sitthicharoenchai D, Chantarasawat N. 2006. Ant species diversity in the establishing area for Advanced Technology Institute at Lai-Nan Subdistrict, Wiang Sa District, Nan Province, Thailand. Nat Hist J Chulalongkorn Univ 6 (2): 67-74.

Suputa, Yamane S, Martono E, Hossain Z, Arminudin AT. 2007. Odontoponera denticulata (Hymenoptera: Formicidae): a potential biological control agent for true fruit flies (Diptera: Tephritidae) in Yogyakarta, Indonesia. Jurnal Ilmu-ilmu Pertanian Indonesa 3: 351356.

Widhiono I, Darsono, Fasihah N. 2017. Endemic species of dung beetles (Coleoptera: Scarabaeidae) on the southern slope of Mount Slamet, Central Java, Indonesia. Biodiversitas 18 (1): 283-287.

Yudiyanto Y, Qayim I, Munif A, Setiadi D, Rizal A. 2014. Diversity and community structure of ants in pepper plantation, Lampung Province. Jurnal Entomologi Indonesia 11 (2): 65-71.

Yuniar N, Haneda NF. 2015. Ants diversity in four different ecosystem types in Jambi. Pros Sem Nas Masy Biodiv Indon 1 (7): 1582-1585. [Indonesia] 